in vivo $35: 1285-1294(2021)$

doi:10.21873/invivo.12380

Review

\title{
The Experience of Greece as a Model to Contain COVID-19 Infection Spread
}

\author{
GEORGE J. DELINASIOS ${ }^{1}$, PARASKEVI C. FRAGKOU ${ }^{2}$, ATHINA M. GKIRMPA $^{3}$, \\ GEORGE TSANGARIS $^{3}$, ROBERT M. HOFFMAN ${ }^{4,5}$ and ATHANASIOS K. ANAGNOSTOPOULOS ${ }^{1,3}$ \\ ${ }^{1}$ International Institute of Anticancer Research, Kapandriti, Greece; \\ ${ }^{2}$ Fourth Department of Internal Medicine, Attikon University Hospital, \\ National and Kapodistrian University of Athens, Athens, Greece; \\ ${ }^{3}$ Biomedical Research Foundation of the Academy of Athens, Athens, Greece; \\ ${ }^{4}$ AntiCancer Inc., San Diego, CA, U.S.A.; \\ ${ }^{5}$ Department of Surgery, University of San Diego, San Diego, CA, U.S.A.
}

\begin{abstract}
The severe acute respiratory syndrome corona virus 2 (SARS-CoV-2) emerged in late 2019 and has caused a pandemic known as corona virus disease 2019 (COVID-19), responsible for the death of more than 2 million people worldwide. The outbreak of COVID-19 has posed an unprecedented threat on human lives and public safety. The aim of this review is to describe key aspects of the bio-pathology of the novel disease, and discuss aspects of its spread, as well as targeted protective strategies that can help shape the outcome of the present and future health crises. Greece is used as a model to inhibit SARS-COV-2 spread, since it is one of the countries with the lowest fatality rates among nations of the European Union (E.U.), following two consecutive waves of COVID-19 pandemic. Furthermore, niche research technological approaches and scientific recommendations that emerged during the COVID-19 era are discussed.
\end{abstract}

Since its initial zoonotic spillover event in China (November 2019), severe acute respiratory syndrome corona virus 2

This article is freely accessible online.

Correspondence to: Dr. Athanasios Anagnostopoulos, Biomedical Research Foundation of the Academy of Athens, 4 Soranou Ephessiou Street, 11527 Athens, Greece. Tel: +30 2106597383 , e-mail: atanagnost@biocademy.gr and Dr. George Delinasios, International Institute of Anticancer Research, 1st km KapandritiouKalamou Road, P.O. Box 22, 19014 Kapandriti, Greece. Tel: +30 2295053389, e-mail: george.delinasios@iiar-anticancer.org

Key Words: SARS-CoV-2, COVID-19, pandemic, epidemiology, population screening, laboratory medicine, policymaking, Greece, targeted protective measures, review.
(SARS-CoV-2) has been affecting humans on a global scale. Health care systems worldwide have been challenged at an unprecedented scale, leading governments to the adoption of draconian social isolation measures (such as lockdowns). Despite these efforts, global spread of the virus remains uncontrollable. The present review portrays key aspects of the corona virus disease 2019 (COVID-19) bio-pathophysiology and summarizes important pandemic management lessons learned through the lens of the Greek case.

\section{Origin of SARS-CoV-2}

There are seven human coronaviruses (HCoVs) genera currently identified and clustered as alphacoronaviruses and betacoronaviruses. Out of the seven genera, four strains are circulating in the human population and in animals are known to cause $10-15 \%$ of cases of the common cold (alphacoronaviruses - HCoV-NL63, HCoV-229E, HCoVOC43 and HCoV-HKU1). Three zoonotic betacoronaviruses have emerged in the human population due to species jumping or zoonotic transfer; SARS-CoV, MERS-COV and SARS-CoV-2, all of which have common ancestors in bat viruses (1). SARS-COV and MERS-COV probably originated from bats but entered the human population through one or more intermediate animal hosts. Regarding SARS-CoV the intermediate host was civets (Paguma larvata) and for MERS-COV-1 the intermediate host was the dromedary camels (Camelus dromedarius). In these intermediate hosts the virus underwent rounds of RNA replication leading to mutations that allowed the virus to efficiently transmitted to the human population. Regarding SARS-CoV-2, the intermediate host (if there is one) between bats and humans remains unknown and controversial. 


\section{Pathobiology/Pathophysiology}

Our knowledge on how HCoVs affect humans is relatively new, and most data became available after the outbreak of SARS-CoV in China in 2002 (2, 3). HCoVs are pleomorphic single-stranded, positive-sense RNA viruses with a helical nucleocapsid and a lipid envelope derived from the host cell (4). In humans, these viruses cause primarily respiratory tract infections of variable severity.

Coronaviruses have the largest genomes among RNA viruses with approximately $30 \mathrm{~Kb}$ coding 20 proteins (5). At the molecular level, coronaviruses infect host cells by attaching to their surface and binding to membrane receptors, through the spike (S) proteins of the viral cone. In particular, SARS-CoV-2 entry in the cell is driven by interactions between the viral $\mathrm{S}$ protein and human angiotensin-converting enzyme 2 (ACE2), a cellular membrane receptor. A transmembrane serine protease (TMPRSS4) has been identified to be highly interactive with ACE2. TMPRSS4 facilitates viral entry into host cells by priming the $\mathrm{S}$ protein and augmenting its fusogenic activity (6). Binding of the virus to ACE2 causes a cascade of events, starting with deposition of the nucleocapsid into the cell cytoplasm, while the viral genome becomes subject to translation. Subsequently, the genome cap is methylated at two positions, $\mathrm{N}$ methylation of the first-base guanidine and $\mathrm{C}-\mathrm{O}$ methylation of the following nucleotide (5). These methylations make the SARS-CoV-2 genome resemble the host mRNA and protect the viral genome from intracellular host defenses. Thereafter, the first translated protein, replicase, uses the viral genome to construct all structural and accessory proteins of the new virus, inside the endoplasmic reticulum and Golgi apparatus. Initially, the structural proteins $\mathrm{M}, \mathrm{S}$ and $\mathrm{E}$ are formed, and then nucleocapsids are constructed with the assistance of the $\mathrm{N}$ protein, ultimately leading to the formation of virions. Viral proteins nop14 and ASP16 function as methyltransferases in conjunction with ASP10. Virions are finally exported from infected cells in Golgi sacs, a process that helps them evade human immune surveillance (7). The viral proteins are potential drug targets, especially the methyltransferases which may be inhibited by methionine restriction of the host (8).

At clinical level SARS-CoV-2 infection causes variable clinical syndromes ranging from asymptomatic or mild respiratory infection to severe acute respiratory disease and multi-organ injury. Among those with symptomatic disease, pneumonia appears to be one of the most prevalent and lethal manifestations; common symptoms include fever, tiredness, dry cough, dyspnea, headache, olfactory and gustatory dysfunction while bilateral ground glass lung opacities are often seen in computed tomography (CT) scans (9). Furthermore, upper-respiratory-tract symptoms and signs (such as rhinorrhea) are relatively uncommon (10). However, symptoms of viral infection may vary significantly among individuals, as there are cases where patients initially reported gastrointestinal symptoms (nausea, vomiting and diarrhea) prior to having fever and lower respiratory tract signs (11).

Pathogenicity of severe and critical COVID-19 disease has been linked with a great increase of pro-inflammatory cytokines, a phenomenon termed "cytokine storm". This can result in hyperactivation of the immune system and lead to pulmonary and multi-organ damage. Some COVID-19 patients have exhibited both leucopenia and lymphopenia (white cells $<4 \times 10^{9} / 1$ and lymphocytes $<10^{9} / 1$, respectively) with initial interleukin values (IL1B, IL1RA, IL7-10) as well as interferon gamma (IFN $\gamma$ ), tumor necrosis factor alpha (TNF $\alpha$ ) and vascular endothelial growth factor (VEGF) concentrations much higher than normal (12). SARS-CoV-2 infection causes systemic disease, involving multiple organs and systems (13). Cytokine storm leads to extensive vascular damage and eventual multiorgan organ failure. Several pathways have been described regarding this hyperinflammatory response; briefly, cytokine production is promoted via the NLRP3 inflammasome, a molecular platform shown to participate in disease pathophysiology as well as being a marker correlated to severity of disease $(14,15)$.

Activation of coagulation pathways through direct viral endothelial damage as well as due to overproduction of cytokines, results in a defective procoagulant-anticoagulant balance that is responsible for thrombosis, disseminated intravascular coagulation, and ultimately multi-organ failure (16).

Chest CT scan of COVID-19 patients demonstrate bilateral lobular areas of consolidation as well as bilateral ground glass opacities. The CT imaging findings of SARSCoV-2-infected patients do not differ from those with other causes of viral pneumonia. However, there have been reports of symptomatic cases having negative CTs. This is because despite its high sensitivity $(86.2 \%)$, CT has a very low specificity $(18.1 \%)$. Therefore, the prognostic value of radiology is questioned in the case of COVID-19 as it may lead to false negatives $(17,18)$.

Currently, there are insufficient data on the disease's pathological aspects. In this respect, relevant studies involving post-mortem biopsies seem to provide useful insight on the systemic status of the disease. A study used core needle biopsies of the lung, heart and liver from patients who succumbed to COVID-19, to investigate the pathological aspects of affected organs that led to fatality. The patients were 51-89 years old with previous underlying health conditions. The organs mainly affected were the lungs, showing damage in alveolar epithelial cells, hyaline formation and hyperplasia, while damage in the liver and heart was limited, most likely linked to underlying conditions (19). Varga et al. identified viral inclusion structures in the kidney of a renal transplant patient by electron microscopy. A post-mortem histological examination of another patient revealed lymphocytic 
endotheliitis in the lung, heart, kidney and liver, as well as liver-cell necrosis. Endotheliitis was also observed in the small intestine of a patient; the authors emphasized the presence of diffuse endothelial inflammation caused by SARS-CoV-2, since the ACE2 receptor is present in epithelial cells of multiple organs. The widespread endothelial dysfunction leading to apoptotic death of these cells may be caused by either direct viral insult or as a result of hyper-activated immune response (20).

\section{Transmission}

There are numerous reports on how SARS-CoV-2 is transmitted, with contradictory findings. The general consensus is that viral transmission occurs mainly through droplet transmission during direct and close interaction with an infected individual, or via airborne transmission during aerosol-producing procedures or indirectly through contact with viral emissions from the individual, such as droplets remaining on surfaces, or through fomites on surfaces that the individual has touched (21-24). Several other reports have, in fact, revealed that the air is the main transmission route for $\mathrm{CoV}$ in indoor settings $(25,26)$. Indeed, a recent study revealed that aerosol and fomite transmission of SARS-CoV-2 occurs and the virus can remain active in aerosols for hours, and on surfaces for days after excretion from an infected individual (27). Important findings estimate a person to be most infectious when viral shedding is at its maximum; this happens on or before symptom onset. Accordingly, the use of facial mask is essential to prevent spread of the disease (28). Compulsory use of masks has therefore been implemented in most countries, following the Chinese model to control spreading events.

Another crucial aspect, related to COVID-19 epidemiology is the role of children in disease transmission. Importantly, very low rates of pediatric COVID-19 patients have been reported compared to adults. This population is potentially under-represented in this pandemic due to specific mechanisms existing in children that regulate the interaction between the respiratory and immune system, which could potentially lead to milder or even asymptomatic phenotypes. However, the low prioritization of children in COVID-19 testing due to the asymptomatic nature of the infection as well as the low risk for disease progression, may also contribute to an underestimated incidence of SARSCoV-2 infection among the pediatric population $(29,30)$. A study showed that children are clearly susceptible to SARSCoV-2 infection, and therefore they are able to transmit the virus. Another study investigating a large primary dataset of cases and close contacts with sufficient documentation of surveillance modes, showed that $7 \%$ of close contacts younger than age 10 became infected, a percentage that is roughly the same as in the overall population $(31,32)$. The exact role of children in the onwards transmission of the virus remains controversial $(33,34)$, and school policies greatly vary from country to country.

With regard to sex predilection for severe disease, remarkable differences have been observed in immune response between men and women, underlining the key role of immune regulatory genes encoded by the $\mathrm{X}$ chromosome in females leading to lower viral load levels, and less inflammation compared to men (35).

Since a superspreading event of SARS-CoV that occurred within a housing block in Hong Kong in 2003, the World Health Organization (WHO) published a report stating that the wastewater plumbing system can facilitate viral transmission (36). In this respect, the existence of adequate viral load in wastewater systems inside high-risk transmission settings, such as health care centers and hospitals, in combination with the ability of SARS-CoV-2 to be transmitted through droplet nuclei (airborne transmission), should be dealt with caution and taken into consideration in order to minimize disease spread (37).

Another important issue is whether the virus can pass between domestic animals and humans. It is important to understand if cats and dogs are susceptible to the virus since these animals are in close contact to humans. A research group showed that cats can be infected by SARS-CoV-2, but the animals did not show any symptoms of the disease; the mode of viral spread between animals remains unclear, but contaminated feaces and urine is a possible route of viral spread (38). Already, several cases have been associated with farmed minks, which can act as a reservoir of SARS-CoV-2, passing the virus between them, posing a risk for virus spillover to humans (39). This highlights the need to further study the role of animals in disease transmission.

Finally, with regard to how environmental factors may affect the spread of COVID-19, a large study across four European countries, showed that both cold and dry environment are likely to facilitate viral transmission (40).

\section{Epidemiological Aspects - The Greek Experience}

"First Pandemic Wave": March-June 2020. Greece has a population of $11,184,000$ with an average life expectancy of 79 and 84 years for males and females, respectively (41). The median age of Greek inhabitants is 44.9 years. Importantly, $21.3 \%$ of Greeks are over the age of 65 years old, thus Greece has the second oldest population among other European Union countries, right below Italy (22\%). The high percentage of aged inhabitants inevitably sets Greece among the countries with the most susceptible population for severe COVID-19 disease and poor outcomes.

The first COVID-19 case was reported in Greece on February $26^{\text {th }}, 2020$. As of June $20^{\text {th }}, 2020$ (the estimated date of the first pandemic wave waning in Greece), Greece had 


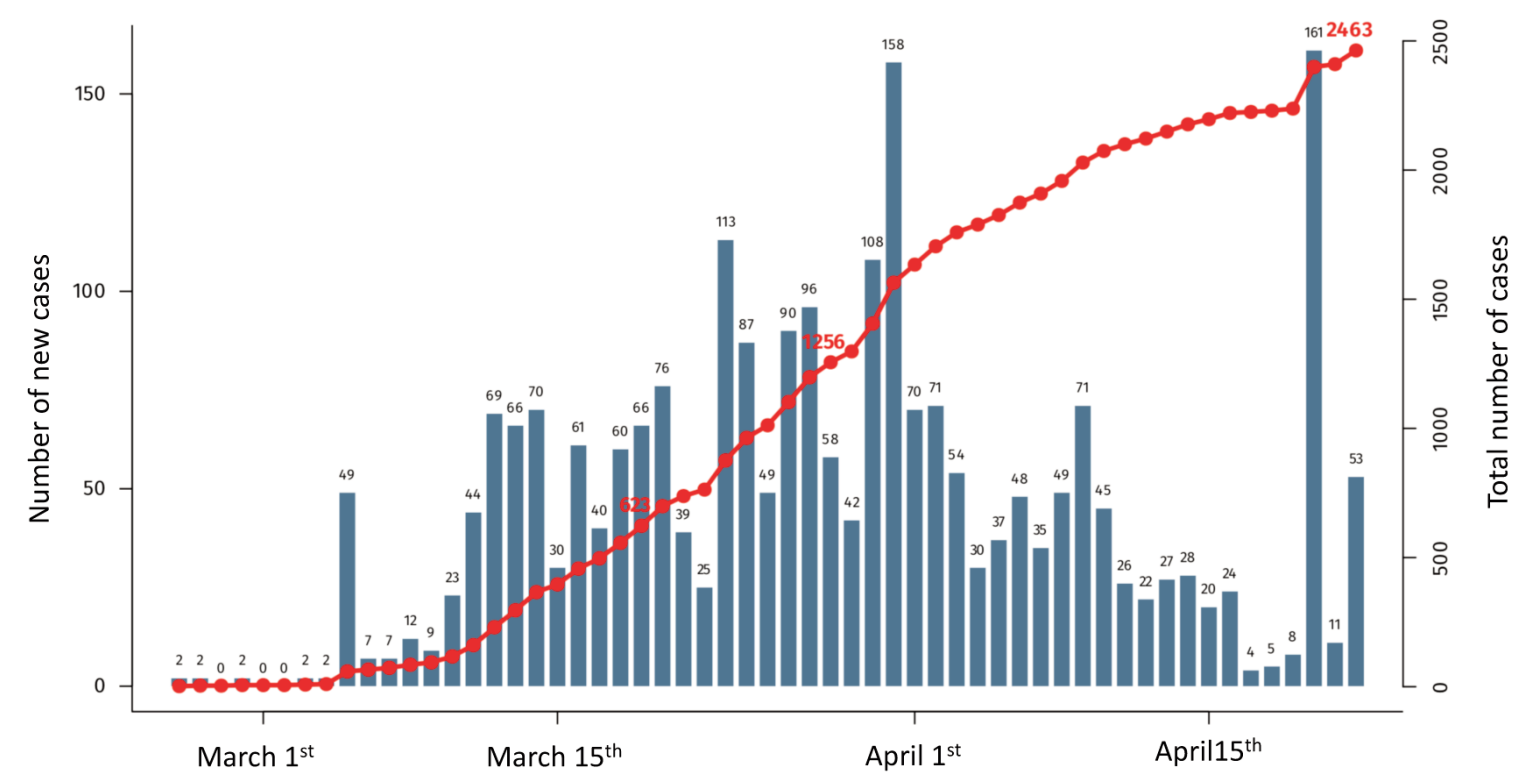

Figure 1. Number of confirmed COVID-19 cases in Greece as of April $23^{\text {rd }} 2020$.

Table I. Age distribution of patients diagnosed with COVID-19 in Greece as of April 23rd, 2020.

\begin{tabular}{lccc}
\hline & $\begin{array}{c}\text { Total COVID-19 cases } \\
\text { (percent of total) }\end{array}$ & $\begin{array}{c}\text { Number of } \\
\text { deaths }\end{array}$ & $\begin{array}{c}\text { Patients in intensive } \\
\text { care units (ICU) }\end{array}$ \\
\hline 0-17 years & $80(3.6 \%)$ & $0(0 \%)$ & $1(1.9 \%)$ \\
18-39 years & $694(30.9 \%)$ & $2(1.6 \%)$ & $0(0 \%)$ \\
40-64 years & $984(43.8 \%)$ & $30(24 \%)$ & $25(48.1 \%)$ \\
$>65$ years & $490(21.8 \%)$ & $93(74.4 \%)$ & $26(50 \%)$ \\
\hline
\end{tabular}

3,256 confirmed cases of SARS-CoV-2 infection (Figure 1). This is a 29.11 rate of cases per 100,000 population compared to 878.4 in Sweden, a country with comparable population (42). Among a total of 278,895 tests performed for SARS-COV-19, in Greece, the positivity rate was $1.9 \%$ (43). Confirmed cases had a mean age of 49 years old (Table I), while $55.6 \%$ were males. A total of 580 cases were related to travelling abroad, and 1,560 cases were close contacts of confirmed cases; no known source of infection was found for the remaining ones.

At the end of first wave, there were 48 COVID-19 patients being treated in intensive care units (ICU) across the country (13 women and 35 men). Their mean age was 67 years and $88 \%$ had at least one underlying comorbidity factor and/or advanced age (>70 years old). Moreover, 190 deaths of patients with COVID-19 (38 women and 92 men) with a mean age of 74 years (Table I) were recorded at that time. About $90 \%$ of the fatal cases had previous serious health conditions and/or age $>70$ years (43).
Greece's most affected area was the prefecture of Attica including the capital city, Athens, where almost half of its population resides. The second most affected region was that of central Macedonia (Figure 2) including Greece's second largest city, Thessaloniki. Few clusters of infected individuals were scattered across Central Greece and the prefecture of Thessaly, in the north-eastern part of the Peloponnese and the region of Evros including the GreekTurkish border. Interestingly, no cases of SARS-COV-2 infection have been recorded in the prefecture of Sterea Ellada, the entire region of Khalkidhiki, as well as the island of Chios, until the end of the first wave.

The Greek approach to contain the pandemic was shaped by the country's financial capacity and the national healthcare system's readiness; during the first wave, Greece was not capable of scaling-up COVID-19 testing to a massive population-based approach, like e.g. Germany (44) or to ensure a sufficient number of ventilators and intensive 


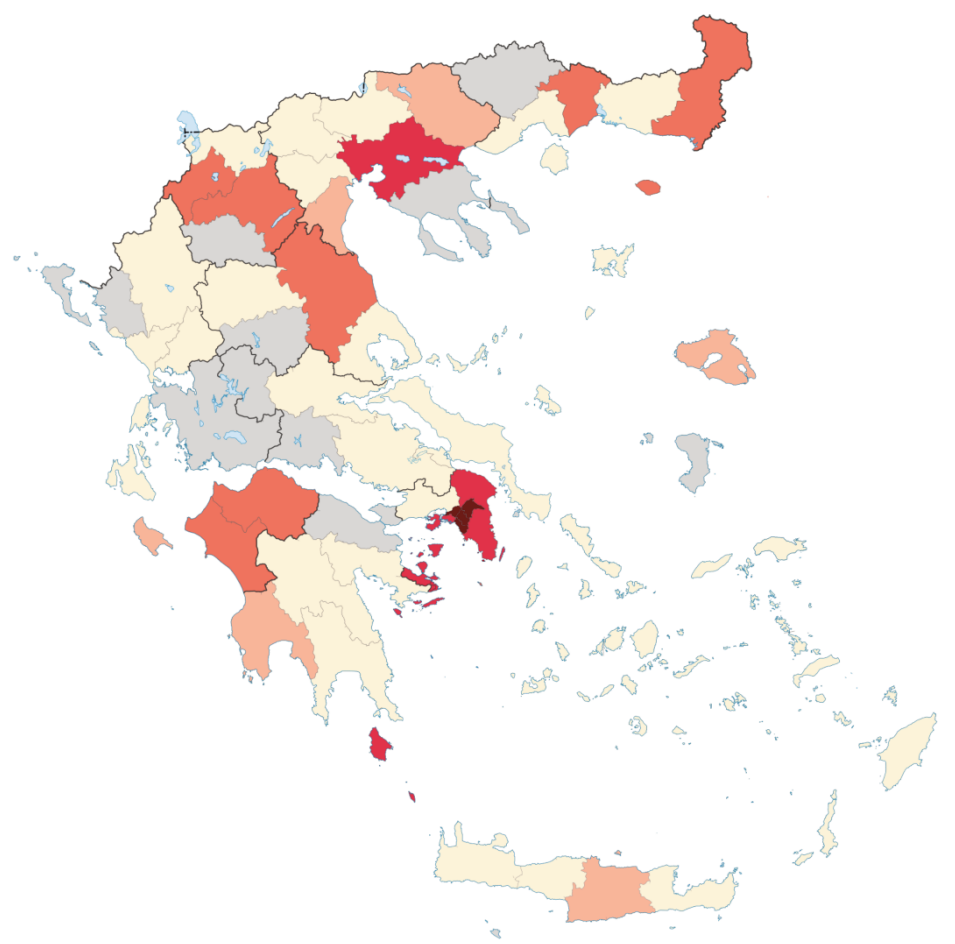

Figure 2. Map of COVID-19 cases distributed in Greece as of April 15th 2020 per regional unit (prefecture). Light pink: 1-4 confirmed cases; pink: 5 9 confirmed cases; light red: 10-49 confirmed cases; red: 50-99 confirmed cases; light brown: 100-199 confirmed cases; brown: $>200$ confirmed cases.

care infrastructure to care for all patients with COVID-19 requiring critical care (45). On this basis, COVID-19 pandemic would have been devastating in Greece, if effective public health and physical/social distancing measures were not implemented early enough.

\section{Effective Adopted Protective Strategies During the "First Pandemic Wave" in Greece}

In Europe, most governments dealt promptly with the COVID-19 pandemic, by imposing restrictions on social interactions and public transportation, but in some countries, such as Italy and Spain, restriction measures were delayed, resulting in catastrophic numbers of casualties.

In Greece, containment measures were implemented as early as the first case of COVID-19 was discovered. Control measures began with cancelation of public festivities and followed by the closure of schools and universities, on March $10^{\text {th }}, 2020$ and two days later, malls, cafeterias and restaurants were locked down. Finally, on March $23^{\text {rd }}$ a nationwide travelling restriction was enforced. Of note, Greece declared a national lockdown when the number of active COVID-19 cases was as low as 695 patients across the country.

This strategy of acting swiftly and adopting containment policies before any casualties, along with the willingness of
Greek communities to adopt and support the imposed measures, led to a highly successful result against the COVID-19 pandemic, at least during the first wave. Importantly, Greece had the third lowest case fatality rate (5\%) amongst European countries with a comparable population, and the lowest actual number of deaths (Table II) during the first wave.

Following the end of the "first wave" (end of June 2020), several factors contributed to an increased number of cases and deaths in Greece were: (i) more than 5 million tourists visited Greece in the next 4 months; (ii) Greece has the second oldest population in the E.U., as discussed above; (iii) poorly-equipped hospitals - approximately only 1,000 ICU beds in hospitals across the country (10 beds per 100,000 people, although the number has now increased significantly); (iv) a health care sector ravaged by austerity and an economy being nearly $40 \%$ smaller than what it was in 2008, before the last global financial crisis.

The epidemiological data of COVID-19 in Greece, for the first half of 2020 , can be regarded as a great success, and model for the world, compared to other EU countries. Upon exiting the lockdown on May 5th 2020, Greece entered the next phase of dealing with an anticipated COVID-19 second wave; as in many other countries in the northern hemisphere, the challenge of the national healthcare system's 
in vivo $35: 1285-1294(2021)$

Table II. Comparative depiction of case fatality rates of COVID-19 in European countries of similar population sizes (data of first wave Jan-June 2020).

\begin{tabular}{lcccc}
\hline Country & Population & Deaths from COVID-19 & Confirmed COVID19 cases & Case fatality rate \\
\hline Netherlands & $17,127,246$ & 5,288 & 41,774 & 0.13 \\
Belgium & $11,585,253$ & 8,415 & 51,420 & 0.16 \\
Greece & $10,434,585$ & 148 & 2,678 & 0.05 \\
Czech Republic & $10,708,072$ & 270 & 8,031 & 0.03 \\
Sweden & $10,088,474$ & 3,040 & 24,463 & 0.12 \\
Portugal & $10,202,245$ & 1,105 & 26,715 & 0.04 \\
\hline
\end{tabular}

sustainability as well as the re-implementation of social distancing and other preventative strategies to restrain viral spread until population vaccination, were revisited.

\section{Vaccines and Vaccination Strategies}

At present BNT162b2, from Pfizer-BioNTech, a lipid nanoparticle-formulated, nucleoside-modified mRNA vaccine that encodes a prefusion-stabilized, membrane-anchored SARS-CoV-2 full-length spike protein is a two-dose regimen vaccine that shows $95 \%$ effectiveness in preventing Covid-19 illness (46). Similarly, the mRNA-1273 vaccine from Moderna has thus far shown $94.1 \%$ efficacy in preventing COVID-19 while AZD1222, a vector-based vaccine from Astrazeneca, has thus far shown $62-90 \%$ efficiency $(47,48)$. These vaccines were recently approved by the US Food and Drug Administration and/or the European Medicines Agency and mass vaccination programmes have started or are about to start.

The COVID-19 experience is shaping the future of vaccine research and development. Since December 2020, the developers of several vaccines had announced very promising results in large trials, and over time more trials confirmed initial enthusiasm. These results have indicated that the vaccine development process can be significantly accelerated, but the major requirement is to not compromise on safety. Since allergic reactions in people who received the COVID-19 vaccine produced by Pfizer and BioNTech in December 2020 were reported (49), concerns were raised regarding its safety. The compound most possibly responsible for these anaphylactic episodes is polyethylene glycol (PEG), found in the packaging of the mRNA that forms the vaccine's main ingredient (also present in Moderna's vaccine) $(50,51)$. Although PEGs have never been used before in vaccines, they are found in many drugs, some of which have been shown to trigger anaphylaxis (52), a potentially life-threatening reaction if left untreated. The exact mechanism of PEG-induced anaphylaxis remains unknown; since a small number of people previously exposed to PEG may have increased levels of antibodies against it, these vaccines could potentially put them at risk of an anaphylactic reaction. Although anaphylaxis is a rare risk of drug administration and has a good prognosis when diagnosed and treated promptly and correctly, vaccination centres should have trained staff and the necessary equipment and medicine available to treat such episodes. With the necessary precautionary measures, the benefits of the COVID-19 vaccines have thus far outweighed the risks.

However big the political and media scrutiny on vaccines under development may be, the goal should always remain to achieve efficacy outcomes, critically evaluated with strict scientific merit aimed at clear clinical significance.

\section{The New Era of "Epidemiomics"}

The COVID-19 era, undoubtedly gave rise to novel perspectives on how scientists and governments perceive and deal with matters of public health. Analytical technologies that have been maturing for decades are now sufficiently developed to provide reliable answers on the epidemiological surveillance and determination of genetic variants on disease susceptibility and severity. Genomics, proteomics, epigenomics and metabolomics are in the frontline against infectious diseases, studying the phylogenetic lineage of viruses, tracing the genotypic variation of viral transmission paths, and understanding the evolutionary biology and spread of communicable diseases. Such approaches may provide new opportunities for epidemiological studies to understand the correlation between the genetic basis of predisposition and the dismal or favourable prognosis to an infectious disease within a population as well as the course of this same disease within an individual patient (53). Research of this type has already started showing promising results; in the UK a genome-wide association study was conducted, comparing critically ill COVID-19 patients with controls form various genetic cohorts, towards understanding the host mechanisms leading to a more severe disease phenotype. Five host genes (FNAR2, TYK2, OAS1, DPP9 and CCR2) have been discovered thus far that are associated with disease severity (54).

Omics and epidemiology ("epidemiomics"), in a symbiotic relationship, will allow the implementation of personalised medicine based on individual omic data of patients: "omics" centres can screen large numbers of 
samples leading to discovery of susceptibility alleles that in combination with phylogenetic scores will predict disease outcome (55). This could lead to individualisation of protective measures and treatments. Through evidence-based identification of population groups at risk and patient stratification based on individualised profiling, an effective targeted preventive strategy can be crafted $(56,57)$.

An effective global strategy against pandemics is necessary. The need for collective societal response on this behalf is more important than ever. Pathogens of zoonotic or agricultural origin with high mutation and gene recombination rates, constitute a huge pool of global health threats (58). The human-animal interphase in the context of disease generation must be thoroughly reconsidered, even if this means that a ban on selling wild-caught animals in wet markets must be imposed. Although vaccines and therapeutic alternatives are good responses to the problem, they are still responses; prevention is much more effective and should precede them.

\section{Take Home Messages}

Epidemiological studies are highly anticipated to produce accurate infection rates and shed light on many questions such as the transmissibility of the virus in the Greek climate (high summer temperature, increased UV from sunlight, vitamin D synthesis, and temperate climate).

Whilst examining the case of Greece, it becomes clear that in order to adopt preventive strategies that work, health care systems worldwide must rely on case-specific multi-parametric predictive models. To address the multi-phased aspects of the COVID-19 pandemic, key factors such as the real number of infected persons in each country as well as the exact personalised characteristics of individuals predisposed to severe disease forms, need to be taken in consideration.

In Greece, as in many other countries worldwide, the lack of nation-wide testing strategies during the first wave, could have led to an underestimation of the actual number of reported cases. Population-wide access to molecular (and/or accurate antigen-based) COVID-19 tests, that could facilitate the prompt isolation of confirmed cases and the precise contact tracing, might have accelerated the exiting strategy from the lockdown that had a huge economic burden for societies. In Greece, the shortage of consumables globally due to the pandemic, the lack of sufficient infrastructure, healthcare facilities and logistics across the country, the limited number of personnel trained to perform such laboratory-based molecular testing and the insufficient evidence on the accuracy of non-approved tests, led to the adoption of a very effective symptom-based isolation and the implementation of strict social distancing measures during the first wave. It should be noted, however, that both models compel huge financial sacrifices, and it still remains unclear which testing/prevention strategy works better in terms of a bearable socioeconomic burden with the lowest possible loss of human lives. Surely, one size does not fit all; hence, the implementation of different approaches to combat this and (maybe) future pandemics/epidemics on a country-wide basis, should comply with the available resources, the specific cultural traits of each population and the social/economic needs of each country. Undoubtedly, the ultimate goal for all prevention models should be the prioritization of human lives and the society's well-being.

No matter how efficient a model may be in theory, the success is ultimately defined by the willingness of each society to comply with the necessary measures. To this end, public sharing of information and precise justification of the role and purpose of such measures by authorities, encourage the development of mutual trust that is paramount for the successful implementation of each strategy. This approach, which was followed by the Greek government, proved unequivocally rewarding in terms of population compliance. However, the era of social media domination and information overload in general, has unavoidably led not only to excessive anxiety and depression phenomena, but also to misinformation and conspiracy theories globally. The latter, and more importantly the economic and emotional exhaustion of the population from the prolonged lockdown, generated different degrees of public distrust to the measures. This has been augmented by the inconsistency of the data shared with the public during the different phases of the pandemic; although this phenomenon is well-known to the scientific community, which acknowledges that evidence evolves and parallels research, for some lay people such messages seem conflicting and amplify their suspicion and sense of uncertainty. Thus, it is imperative to assemble special crisis response groups comprising of experts that can efficiently articulate and communicate the need for each measure to the public. Each decision needs to be explained, dissected and analyzed to the extent needed to counterbalance the organic opposition the population is bound to lean towards, especially given a financial crisis similar to the one that preceded COVID-19 in the Greek society.

Furthermore, retrospective analysis of data is required to adjust for future epidemic scenarios, in order for prediction to be more accurate. The combination of multi-professional expertise such as laboratory medicine, omics research, epidemiology, virology and all other disciplines of science can help achieve targeted prevention. The example of Greece suggests that strategic measures and trust amongst the population can reduce COVID-19 spread while avoiding draconian measures similar to the ones taken in China.

\section{Compliance With Ethical Standards}

The article follows international standards on ethics: only officially published data on Covid-19 have been considered for the publication. 


\section{Conflicts of Interest}

The Authors declare that they have no conflicts of interest.

\section{Authors' Contributions}

GJD and AKA conceived the project, supervised the study and did most of the writing. PCF wrote the commentary section regarding the socioeconomic burdens and future ways to act. AMG performed bibliographical search and assisted in editing and writing. RMH contributed in the structure of the manuscript and critically revised it at all stages. GT revised the final draft. All Authors have read and approved the final version of the manuscript.

\section{References}

1 Wu L, Zhou P, Ge X, Wang L, Baker M and Shi Z: Deep RNA sequencing reveals complex transcriptional landscape of a bat adenovirus. Journal of Virology 87(1): 503-511, 2020. DOI: 10.1128/JVI.02332-12

2 Zhong NS, Zheng BJ, Li YM, Poon, Xie ZH, Chan KH, Li PH, Tan SY, Chang Q, Xie JP, Liu XQ, Xu J, Li DX, Yuen KY, Peiris and Guan Y: Epidemiology and cause of severe acute respiratory syndrome (SARS) in Guangdong, People's Republic of China, in February, 2003. Lancet 362(9393): 1353-1358, 2003. PMID: 14585636. DOI: 10.1016/s0140-6736(03)14630-2

3 Cui J, Han N, Streicker D, Li G, Tang X, Shi Z, Hu Z, Zhao G, Fontanet A, Guan Y, Wang L, Jones G, Field HE, Daszak P and Zhang S: Evolutionary relationships between bat coronaviruses and their hosts. Emerg Infect Dis 13(10): 1526-1532, 2007. PMID: 18258002. DOI: 10.3201/eid1310.070448

4 Cui J, Li F and Shi ZL: Origin and evolution of pathogenic coronaviruses. Nat Rev Microbiol 17(3): 181-192, 2019. PMID: 30531947. DOI: 10.1038/s41579-018-0118-9

5 Krafcikova P, Silhan J, Nencka R and Boura E: Structural analysis of the SARS-CoV-2 methyltransferase complex involved in RNA cap creation bound to sinefungin. Nat Commun 11(1): 3717, 2020. PMID: 32709887. DOI: 10.1038/s41467-020-17495-9

6 Wruck W and Adjaye J: SARS-CoV-2 receptor ACE2 is coexpressed with genes related to transmembrane serine proteases, viral entry, immunity and cellular stress. Sci Rep 10(1): 21415, 2020. PMID: 33293627. DOI: 10.1038/s41598-020-78402-2

7 Masters PS: The molecular biology of coronaviruses. In: Advances in virus research. Academic Press, pp. 193-292, 2006.

8 Hoffman RM and Han Q: Oral Methioninase for Covid-19 Methionine-restriction Therapy. In Vivo 34(3 Suppl): 1593-1596, 2020. PMID: 32503816. DOI: 10.21873/invivo.11948

9 Mizrahi B, Shilo S, Rossman H, Kalkstein N, Marcus K, Barer Y, Keshet A, Shamir-Stein N, Shalev V, Zohar AE, Chodick G and Segal E: Longitudinal symptom dynamics of COVID-19 infection. Nat Commun 11(1): 6208, 2020. PMID: 33277494. DOI: $10.1038 / \mathrm{s} 41467-020-20053-y$

10 Calabrese F, Pezzuto F, Fortarezza F, Hofman P, Kern I, Panizo A, von der Thüsen J, Timofeev S, Gorkiewicz G and Lunardi F: Pulmonary pathology and COVID-19: lessons from autopsy. The experience of European Pulmonary Pathologists. Virchows Arch 477(3): 359-372, 2020. PMID: 32642842. DOI: 10.1007/s00428020-02886-6
11 COVID-19 Investigation Team.: Clinical and virologic characteristics of the first 12 patients with coronavirus disease 2019 (COVID-19) in the United States. Nat Med 26(6): 861-868, 2020. PMID: 32327757. DOI: 10.1038/s41591-020-0877-5

12 Huang C, Wang Y, Li X, Ren L, Zhao J, Hu Y, Zhang L, Fan G, Xu J, Gu X, Cheng Z, Yu T, Xia J, Wei Y, Wu W, Xie X, Yin W, Li H, Liu M, Xiao Y, Gao H, Guo L, Xie J, Wang G, Jiang R, Gao Z, Jin Q, Wang J and Cao B: Clinical features of patients infected with 2019 novel coronavirus in Wuhan, China. Lancet 395(10223): 497-506, 2020. PMID: 31986264. DOI: 10.1016/S0140-6736(20)30183-5

13 Skevaki C, Fragkou PC, Cheng C, Xie M and Renz H: Laboratory characteristics of patients infected with the novel SARS-CoV-2 virus. J Infect 81(2): 205-212, 2020. PMID: 32579986. DOI: 10.1016/j.jinf.2020.06.039

14 Rodrigues TS, de Sá KSG, Ishimoto AY, Becerra A, Oliveira S, Almeida L, Gonçalves AV, Perucello DB, Andrade WA, Castro R, Veras FP, Toller-Kawahisa JE, Nascimento DC, de Lima MHF, Silva CMS, Caetite DB, Martins RB, Castro IA, Pontelli MC, de Barros FC, do Amaral NB, Giannini MC, Bonjorno LP, Lopes MIF, Santana RC, Vilar FC, Auxiliadora-Martins M, Luppino-Assad R, de Almeida SCL, de Oliveira FR, Batah SS, Siyuan L, Benatti MN, Cunha TM, Alves-Filho JC, Cunha FQ, Cunha LD, Frantz FG, Kohlsdorf T, Fabro AT, Arruda E, de Oliveira RDR, Louzada-Junior $\mathrm{P}$ and Zamboni DS: Inflammasomes are activated in response to SARS-CoV-2 infection and are associated with COVID-19 severity in patients. J Exp Med 218(3): e20201707, 2021. PMID: 33231615. DOI: 10.1084/jem.20201707

15 Bhaskar S, Sinha A, Banach M, Mittoo S, Weissert R, Kass JS, Rajagopal S, Pai AR and Kutty S: Cytokine storm in COVID19-immunopathological mechanisms, clinical considerations, and therapeutic approaches: The REPROGRAM consortium position paper. Front Immunol 11: 1648, 2020. PMID: 32754159. DOI: 10.3389/fimmu.2020.01648

16 Jose RJ and Manuel A: COVID-19 cytokine storm: the interplay between inflammation and coagulation. Lancet Respir Med 8(6): e46-e47, 2020. PMID: 32353251. DOI: 10.1016/S22132600(20)30216-2

17 Hope MD, Raptis CA, Shah A, Hammer MM, Henry TS and six signatories.: A role for CT in COVID-19? What data really tell us so far. Lancet 395(10231): 1189-1190, 2020. PMID: 32224299. DOI: 10.1016/S0140-6736(20)30728-5

18 Salameh JP, Leeflang MM, Hooft L, Islam N, McGrath TA, van der Pol CB, Frank RA, Prager R, Hare SS, Dennie C, Spijker R, Deeks JJ, Dinnes J, Jenniskens K, Korevaar DA, Cohen JF, Van den Bruel A, Takwoingi Y, van de Wijgert J, Damen JA, Wang J, Cochrane COVID-19 Diagnostic Test Accuracy Group. and McInnes MD: Thoracic imaging tests for the diagnosis of COVID-19. Cochrane Database Syst Rev 9: CD013639, 2020. PMID: 32997361. DOI: 10.1002/14651858.CD013639.pub2

19 Tian S, Xiong Y, Liu H, Niu L, Guo J, Liao M and Xiao SY: Pathological study of the 2019 novel coronavirus disease (COVID19) through postmortem core biopsies. Mod Pathol 33(6): 10071014, 2020. PMID: 32291399. DOI: 10.1038/s41379-020-0536-x

20 Varga Z, Flammer AJ, Steiger P, Haberecker M, Andermatt R, Zinkernagel AS, Mehra MR, Schuepbach RA, Ruschitzka F and Moch H: Endothelial cell infection and endotheliitis in COVID19. Lancet 395(10234): 1417-1418, 2020. PMID: 32325026. DOI: 10.1016/S0140-6736(20)30937-5 
21 Morawska L: Droplet fate in indoor environments, or can we prevent the spread of infection?. Indoor Air 16(5): 335-347, 2006. PMID: 16948710. DOI: 10.1111/j.1600-0668.2006.00432.x

22 Alsved M, Matamis A, Bohlin R, Richter M, Bengtsson P, Fraenkel $\mathrm{C}$, Medstrand $\mathrm{P}$ and Löndahl J: Exhaled respiratory particles during singing and talking. Aerosol Science and Technology 54(11): 12451248, 2020. DOI: 10.1080/02786826.2020.1812502

23 Yu IT, Li Y, Wong TW, Tam W, Chan AT, Lee JH, Leung DY and Ho T: Evidence of airborne transmission of the severe acute respiratory syndrome virus. N Engl J Med 350(17): 1731-1739, 2004. PMID: 15102999 . DOI: $10.1056 /$ NEJMoa032867

24 Azimi P, Keshavarz Z, Cedeno Laurent JG, Stephens B and Allen JG: Mechanistic transmission modeling of COVID-19 on the Diamond Princess cruise ship demonstrates the importance of aerosol transmission. Proc Natl Acad Sci USA 118(8): e2015482118, 2021. PMID: 33536312. DOI: 10.1073/pnas.20154 82118

25 Xiao S, Li Y, Wong TW and Hui DSC: Role of fomites in SARS transmission during the largest hospital outbreak in Hong Kong. PLoS One 12(7): e0181558, 2017. PMID: 28727803. DOI: 10.1371/journal.pone. 0181558

26 Olsen SJ, Chang HL, Cheung TY, Tang AF, Fisk TL, Ooi SP, Kuo HW, Jiang DD, Chen KT, Lando J, Hsu KH, Chen TJ and Dowell SF: Transmission of the severe acute respiratory syndrome on aircraft. N Engl J Med 349(25): 2416-2422, 2003. PMID: 14681507. DOI: 10.1056/NEJMoa031349

27 van Doremalen N, Bushmaker T, Morris DH, Holbrook MG, Gamble A, Williamson BN, Tamin A, Harcourt JL, Thornburg NJ, Gerber SI, Lloyd-Smith JO, de Wit E and Munster VJ: Aerosol and surface stability of SARS-CoV-2 as compared with SARS-CoV-1. N Engl J Med 382(16): 1564-1567, 2020. PMID: 32182409. DOI: 10.1056/NEJMc2004973

28 He X, Lau EHY, Wu P, Deng X, Wang J, Hao X, Lau YC, Wong JY, Guan Y, Tan X, Mo X, Chen Y, Liao B, Chen W, Hu F, Zhang Q, Zhong M, Wu Y, Zhao L, Zhang F, Cowling BJ, Li F and Leung GM: Temporal dynamics in viral shedding and transmissibility of COVID-19. Nat Med 26(5): 672-675, 2020. PMID: 32296168. DOI: 10.1038/s41591-020-0869-5

29 Williams N, Radia T, Harman K, Agrawal P, Cook J and Gupta A: COVID-19 Severe acute respiratory syndrome coronavirus 2 (SARS-CoV-2) infection in children and adolescents: a systematic review of critically unwell children and the association with underlying comorbidities. Eur J Pediatr: 1-9, 2020. PMID: 32914200. DOI: 10.1007/s00431-020-03801-6

30 Laws RL, Chancey RJ, Rabold EM, Chu VT, Lewis NM, Fajans M, Reses HE, Duca LM, Dawson P, Conners EE, Gharpure R, Yin S, Buono S, Pomeroy M, Yousaf AR, Owusu D, Wadhwa A, Pevzner E, Battey KA, Njuguna H, Fields VL, Salvatore P, O'Hegarty M, Vuong J, Gregory CJ, Banks M, Rispens J, Dietrich E, Marcenac P, Matanock A, Pray I, Westergaard R, Dasu T, Bhattacharyya S, Christiansen A, Page L, Dunn A, Atkinson-Dunn R, Christensen K, Kiphibane T, Willardson S, Fox G, Ye D, Nabity SA, Binder A, Freeman BD, Lester S, Mills L, Thornburg N, Hall AJ, Fry AM, Tate JE, Tran CH and Kirking HL: Symptoms and transmission of SARS-CoV-2 among children - utah and wisconsin, March-May 2020. Pediatrics 147(1): e2020027268, 2021. PMID: 33033178. DOI: 10.1542/peds.2020-027268

31 Kelvin AA and Halperin S: COVID-19 in children: the link in the transmission chain. Lancet Infect Dis 20(6): 633-634, 2020. PMID: 32220651. DOI: 10.1016/S1473-3099(20)30236-X
32 Bi Q, Wu Y, Mei S, Ye C, Zou X, Zhang Z, Liu X, Wei L, Truelove SA, Zhang T, Gao W, Cheng C, Tang X, Wu X, Wu Y, Sun B, Huang S, Sun Y, Zhang J, Ma T, Lessler J and Feng $\mathrm{T}$ : Epidemiology and transmission of COVID-19 in 391 cases and 1286 of their close contacts in Shenzhen, China: a retrospective cohort study. Lancet Infect Dis 20(8): 911-919, 2020. PMID: 32353347. DOI: 10.1016/S1473-3099(20) 30287-5

33 Zhu Y, Bloxham CJ, Hulme KD, Sinclair JE, Tong ZWM, Steele LE, Noye EC, Lu J, Xia Y, Chew KY, Pickering J, Gilks C, Bowen AC and Short KR: A meta-analysis on the role of children in SARS-CoV-2 in household transmission clusters. Clin Infect Dis: ciaa1825, 2020. PMID: 33283240. DOI: 10.1093/cid/ ciaa 1825

34 Rice K, Wynne B, Martin V and Ackland GJ: Effect of school closures on mortality from coronavirus disease 2019: old and new predictions. BMJ 371: m3588, 2020. PMID: 33028597. DOI: $10.1136 /$ bmj.m3588

35 Conti P and Younes A: Coronavirus COV-19/SARS-CoV-2 affects women less than men: clinical response to viral infection. J Biol Regul Homeost Agents 34(2): 339-343, 2020. PMID: 32253888. DOI: $10.23812 /$ Editorial-Conti-3

36 Rapid expert consultation on environmental surveillance of SARS-CoV-2 in wastewater: summary report (2020). Available at: https://www.euro.who.int/en/health-topics/environment-andhealth/water-and-sanitation/publications/2020/rapid-expertconsultation-on-environmental-surveillance-of-sars-cov-2-inwastewater-summary-report-2020 [Last accessed on February 11, 2021]

37 Gormley M, Aspray TJ and Kelly DA: COVID-19: mitigating transmission via wastewater plumbing systems. Lancet Glob Health 8(5): e643, 2020. PMID: 32213325. DOI: 10.1016/ S2214-109X(20)30112-1

38 Mallapaty S: Coronavirus can infect cats - dogs, not so much. Nature, 2020. Available at: https://www.nature.com/articles/d41586020-00984-8 DOI: 10.1038/d41586-020-00984-8 [Last accessed on February 11, 2021]

39 Larsen HD, Fonager J, Lomholt FK, Dalby T, Benedetti G, Kristensen B, Urth TR, Rasmussen M, Lassaunière R, Rasmussen TB, Strandbygaard B, Lohse L, Chaine M, Møller KL, Berthelsen AN, Nørgaard SK, Sönksen UW, Boklund AE, Hammer AS, Belsham GJ, Krause TG, Mortensen S, B $\varnothing$ tner A, Fomsgaard A and Mølbak K: Preliminary report of an outbreak of SARS-CoV-2 in mink and mink farmers associated with community spread, Denmark, June to November 2020. Euro Surveill 26(5): 2100009, 2021. PMID: 33541485. DOI: 10.2807/ 1560-7917.ES.2021.26.5.210009

40 Fu S, Wang B, Zhou J, Xu X, Liu J, Ma Y, Li L, He X, Li S, Niu J, Luo B and Zhang K: Meteorological factors, governmental responses and COVID-19: Evidence from four European countries. Environ Res 194: 110596, 2020. PMID: 33307083. DOI: $10.1016 /$ j.envres.2020.110596

41 World Health Organization. Greece. Available at: https:// www.who.int/countries/grc/en/ [Last accessed on February 11, 2021]

42 COVID-19 situation update for the EU/EEA, as of week 4, updated 4 February 2021. Available at: https://www.ecdc.europa.eu/en/cases2019-ncov-eueea [Last accessed on February 11, 2021]

43 National Organism of Public Health. Available at: https://eody.gov.gr/ [Last accessed on February 11, 2021] 
44 Winter AK and Hegde ST: The important role of serology for COVID-19 control. Lancet Infect Dis 20(7): 758-759, 2020. PMID: 32330441. DOI: 10.1016/S1473-3099(20)30322-4

45 Newton PN, Bond KC, Adeyeye M, Antignac M, Ashenef A, Awab GR, Babar Z-U-D, Bannenberg WJ, Bond KC, Bower J, Breman J, Brock A, Caillet C, Coyne P, Day N, Deats M, Douidy K, Doyle K, Dujardin C, Ejekam CS, Fernández F, Freifeld C, Gill M, Guerin PJ, Harigwo G, Heide L, Horby P, Kaur H, Kayumba PC, Kazuko K, Kelly C, Khuluza F, Kigera S, Lalani M, Lamy M, Lieberman M, Lumpkin M, Mackey T, Naughton B, Newton PN, Nguyen P, Olliaro P, Ozawa S, Patel A, Phanouvong S, Pisani E, Pyzik O, Rägo L, Rahman MS, Ranjit E, Ravinetto R, Richmond D, Singh-Phulgenda S, Venema J, Vogt A, White N, Wirtz VJ and Zaman M: Covid-19 and risks to the supply and quality of tests, drugs, and vaccines. Lancet Glob Health 8(6): e754-e755, 2020. PMID: 32278364. DOI: $10.1016 / \mathrm{S} 2214-109 X(20) 30136-4$

46 Polack FP, Thomas SJ, Kitchin N, Absalon J, Gurtman A, Lockhart S, Perez JL, Pérez Marc G, Moreira ED, Zerbini C, Bailey R, Swanson KA, Roychoudhury S, Koury K, Li P, Kalina WV, Cooper D, Frenck RW Jr, Hammitt LL, Türeci Ö, Nell H, Schaefer A, Ünal S, Tresnan DB, Mather S, Dormitzer PR, Şahin U, Jansen KU, Gruber WC and C4591001 Clinical Trial Group: Safety and efficacy of the BNT162b2 mRNA Covid-19 vaccine. N Engl J Med 383(27): 2603-2615, 2020. PMID: 33301246. DOI: 10.1056/NEJMoa2034577

47 Baden LR, El Sahly HM, Essink B, Kotloff K, Frey S, Novak R, Diemert D, Spector SA, Rouphael N, Creech CB, McGettigan J, Khetan S, Segall N, Solis J, Brosz A, Fierro C, Schwartz H, Neuzil K, Corey L, Gilbert P, Janes H, Follmann D, Marovich M, Mascola J, Polakowski L, Ledgerwood J, Graham BS, Bennett H, Pajon R, Knightly C, Leav B, Deng W, Zhou H, Han $\mathrm{S}$, Ivarsson M, Miller J and Zaks T: Efficacy and safety of the mrna-1273 sars-cov-2 vaccine. N Engl J Med 384(5): 403-416, 2020. PMID: 33378609. DOI: 10.1056/NEJMoa2035389

48 Voysey M, Clemens SAC, Madhi SA, Weckx LY, Folegatti PM, Aley PK, Angus B, Baillie VL, Barnabas SL, Bhorat QE, Bibi S, Briner C, Cicconi P, Collins AM, Colin-Jones R, Cutland CL, Darton TC, Dheda K, Duncan CJA, Emary KRW, Ewer KJ, Fairlie L, Faust SN, Feng S, Ferreira DM, Finn A, Goodman AL, Green CM, Green CA, Heath PT, Hill C, Hill H, Hirsch I, Hodgson SHC, Izu A, Jackson S, Jenkin D, Joe CCD, Kerridge S, Koen A, Kwatra G, Lazarus R, Lawrie AM, Lelliott A, Libri V, Lillie PJ, Mallory R, Mendes AVA, Milan EP, Minassian AM, McGregor A, Morrison H, Mujadidi YF, Nana A, O'Reilly PJ, Padayachee SD, Pittella A, Plested E, Pollock KM, Ramasamy MN, Rhead S, Schwarzbold AV, Singh N, Smith A, Song R, Snape MD, Sprinz E, Sutherland RK, Tarrant R, Thomson EC, Török ME, Toshner M, Turner DPJ, Vekemans J, Villafana TL, Watson MEE, Williams CJ, Douglas AD, Hill AVS, Lambe T, Gilbert SC, Pollard AJ and Oxford COVID Vaccine Trial Group.: Safety and efficacy of the ChAdOx1 nCoV-19 vaccine (AZD1222) against SARS-CoV-2: an interim analysis of four randomised controlled trials in Brazil, South Africa, and the UK. Lancet 397(10269): 99-111, 2021. PMID: 33306989. DOI: $10.1016 / \mathrm{S} 0140-6736(20) 32661-1$
49 Glover RE, Urquhart R, Lukawska $\mathrm{J}$ and Blumenthal KG: Vaccinating against covid-19 in people who report allergies. BMJ 372: n120, 2021. PMID: 33461962. DOI: 10.1136/bmj.n120

50 Garvey LH and Nasser S: Anaphylaxis to the first COVID-19 vaccine: is polyethylene glycol (PEG) the culprit? $\mathrm{Br} \mathrm{J}$ Anaesth: S0007, 2020. PMID: 33386124. DOI: 10.1016/j.bja.2020.12.020

51 Moghimi SM, Andersen AJ, Hashemi SH, Lettiero B, Ahmadvand D, Hunter AC, Andresen TL, Hamad I and Szebeni $\mathrm{J}$ : Complement activation cascade triggered by PEG-PL engineered nanomedicines and carbon nanotubes: the challenges ahead. J Control Release 146(2): 175-181, 2010. PMID: 20388529. DOI: 10.1016/j.jconrel.2010.04.003

52 Sellaturay P, Nasser S and Ewan P: Polyethylene Glycol-Induced Systemic Allergic Reactions (Anaphylaxis). J Allergy Clin Immunol Pract 9(2): 670-675, 2021. PMID: 33011299. DOI: 10.1016/j.jaip.2020.09.029

53 Traynor BJ: The era of genomic epidemiology. Neuroepidemiology 33(3): 276-279, 2009. PMID: 19696518. DOI: 10.1159/000235639

54 Pairo-Castineira E, Clohisey S, Klaric L, Bretherick AD, Rawlik K, Pasko D, Walker S, Parkinson N, Fourman MH, Russell CD, Furniss J, Richmond A, Gountouna E, Wrobel N, Harrison D, Wang B, Wu Y, Meynert A, Griffiths F, Oosthuyzen W, Kousathanas A, Moutsianas L, Yang Z, Zhai R, Zheng C, Grimes G, Beale R, Millar J, Shih B, Keating S, Zechner M, Haley C, Porteous DJ, Hayward C, Yang J, Knight J, Summers C, ShankarHari M, Klenerman P, Turtle L, Ho A, Moore SC, Hinds C, Horby P, Nichol A, Maslove D, Ling L, McAuley D, Montgomery H, Walsh T, Pereira A, Renieri A, GenOMICC Investigators, ISARICC Investigators., COVID-19 Human Genetics Initiative., 23andMe Investigators., BRACOVID Investigators., Gen-COVID Investigators, Shen X, Ponting CP, Fawkes A, Tenesa A, Caulfield M, Scott R, Rowan K, Murphy L, Openshaw PJM, Semple MG, Law A, Vitart V, Wilson JF and Baillie JK: Genetic mechanisms of critical illness in Covid-19. Nature, 2020. PMID: 33307546. DOI: $10.1038 / \mathrm{s} 41586-020-03065-\mathrm{y}$

55 Hasin Y, Seldin M and Lusis A: Multi-omics approaches to disease. Genome Biol 18(1): 83, 2017. PMID: 28476144. DOI: 10.1186/s13059-017-1215-1

56 Milani L, Leitsalu L and Metspalu A: An epidemiological perspective of personalized medicine: the Estonian experience. J Intern Med 277(2): 188-200, 2015. PMID: 25339628. DOI: 10.1111 /joim. 12320

57 Chaari L and Golubnitschaja O: Covid-19 pandemic by the "real-time" monitoring: the Tunisian case and lessons for global epidemics in the context of 3PM strategies. EPMA J: 1-6, 2020. PMID: 32341719. DOI: 10.1007/s13167-020-00207-0

58 Kock RA, Karesh WB, Veas F, Velavan TP, Simons D, Mboera LEG, Dar O, Arruda LB and Zumla A: 2019-nCoV in context: lessons learned? Lancet Planet Health 4(3): e87-e88, 2020. PMID: 32035507. DOI: 10.1016/S2542-5196(20)30035-8

Received December 25, 2020

Revised February 10, 2021

Accepted February 11, 2021 